\title{
MEMOIR
}

\section{HAROLD ERNEST RAYNES}

Harold ERnest Raynes died on 3 April 1964 in the 83 ral year of a full and active life. Until his final illness a year or so before his death he had enjoyed good general health, though his hearing had been failing for some years.

He had a first-class intellect, and was never afraid of holding advanced views which were sometimes even regarded as radical during the inter-war years but are now much more generally accepted. His main intellectual interests lay in the economic and social spheres but he maintained throughout his life a considerable keenness for anything concerned with the education of youth and was always ready to give guidance and help to his younger colleagues.

All this is reflected in his early membership of the Fabian Society, his close association with the Reform Club (of which he was chairman on two occasions) and his work on education, not only for the Institute of Actuaries but also for the Chartered Insurance Institute and the London School of Economics.

Actuaries will probably best remember him for his pioneering work in connexion with insured retirement benefit schemes in this country and because he was one of the first to advocate the investment in ordinary shares of part of a life and annuity fund. In regard to the former, he quickly grasped to the full the potentialities of schemes providing benefits for employees in a world which was so obviously ripe for change. He realized, too, that the business was of a different character from that of ordinary life assurance and that, being more permanent, its planning and terms required a long-term view without too much regard to existing conditions. He worked hard during the 1930 s on the development of insured pension schemes and the present strength of such business owes a great deal to him.

In 1927 he wrote a paper to the Institute of Actuaries (J.I.A. 59, 21) pointing out the reasons for hoping that equity share holdings would counterbalance a fall in the value of money and showing, as a matter of history, the advantages which would have accrued to life offices if they had invested part of their funds in ordinary shares. His arguments were not accepted without misgivings at the time and when he wrote another paper on the same subject in 1937 (J.I.A. 68, 483) he was accused by some of 'jobbing back'. Today, however, when the force of his argument is so apparent and offices are in fact heavily invested in equities, it appears that it was another example of forward-thinking. It would be typical of him to have realized that in the world which was to come, control by governments of financial affairs would be intensified and that inflation was likely to become more rather than less common, if only because it is frequently an easy way out of a difficulty.

He wrote other papers to the Institute, in particular one $(J . I . A .65,122)$ describing the family income benefit policy which, since then, has become an important part of most offices' portfolios. He held office as honorary secretary and vice-president of the Institute and was a familiar figure at International Congresses of Actuaries. In 1926 he became the first actuary to qualify by examination as a Fellow of the Chartered Insurance Institute, following which he served for many years on that Institute's Examiners Committee. He was a founder member of its Tuition Committee and served as its treasurer from 1938 to 1950 .

In July 1934 he was appointed to represent the London County Council on the Council of Management and the Court of Governors of the London School of Economics, only relinquishing these appointments in 1963. The Raynes Undergraduate Prize is awarded to the student of the London School of Economics who obtains the best marks at Part I of the Final B.Sc.(Econ.) examination. 
He lived in the Hampstead area throughout his life and was educated at William Ellis School. After leaving school he spent a year with a firm of Lloyds brokers working on marine insurance. In 1901 he joined the staff of the Legal and General Assurance Society Limited with which he spent the remainder of his career. He retired from full-time work in 1945, but remained as the Society's consulting actuary for some years. He joined the board in 1951, resigning as a consequence of deafness in 1961. He was chairman of the Life Offices' Association from 1940 to 1942.

He wrote a number of books on insurance subjects, mainly during his retirement. These included Insurance Companies' Investments (1935), A History of British Insurance (1950), Principles of British Insurance (1953), Social Security in Britain (1957) and Insurance (1960).

He was quick and vigorous in his physical movements as well as quick intellectually. The story still circulates in his office of how, in his middle age, he demonstrated to a number of younger colleagues how to stand on one's head. He played lacrosse in his early days and, later on, discovered the joys of fell walking, sometimes in the company of Sir William Elderton.

H. F. PURCHASE 